\title{
Changes in Lung Surfactant Proteins in Rats With Lipopolysaccharide- -Induced Fever
}

\author{
M. KOLOMAZNIK ${ }^{\mathbf{1}^{*}}$, I. ZILA ${ }^{\mathbf{1}}$, J. KOPINCOVA ${ }^{\mathbf{1}}$, D. MOKRA ${ }^{\mathbf{1}}$, A. CALKOVSKA $^{\mathbf{1}}$ \\ * These authors contributed equally to this work \\ ${ }^{1}$ Department of Physiology, Jessenius Faculty of Medicine in Martin, Comenius University \\ in Bratislava, Martin, Slovakia
}

Received March 16, 2014

Accepted August 3, 2014

\begin{abstract}
Summary
The study was designed to prove the hypothesis that lipopolysaccharide (LPS)-induced fever elicits the changes in surfactant specific proteins, potentially related to thermal tachypnea. In adult rats fever was induced by intraperitoneal administration of LPS at a dose $100 \mu \mathrm{g} / \mathrm{kg}$ of body weight; control group received saline. Respiratory parameters, arterial blood gases and $\mathrm{pH}$ and colonic body temperature (BT) were recorded. Five hours later, surfactant proteins (SP) A, B, C and D were evaluated in bronchoalveolar lavage fluid (BALF) and lung tissue (LT). LPS evoked monophasic thermic response (at $300 \min 38.7 \pm 0.2$ vs. $36.4 \pm 0.3^{\circ} \mathrm{C}, \mathrm{P}<0.05$ ) and an increase in minute ventilation due to changes in breathing rate and tidal volume. LPS-instilled animals had higher levels of SP-A and SP-D in $L T(P<0.05$ and 0.01$)$, and higher SP-D in BALF $(P<0.01)$ than controls. SP-B increased in LT and SP-C in BALF of animals with LPS (both $P<0.05$ vs. controls). The changes in all surfactant specific proteins are present in LPS-induced fever. Alterations of proteins related to local immune mechanisms (SP-A, SP-D) are probably a part of general inflammatory response to pyrogen. Changes in proteins related to surface activity (SP-B and SP-C) might reflect the effort of the body to stabilize the lungs in thermal challenge.
\end{abstract}

\section{Key words}

Surfactant specific proteins • Lipopolysaccharide • Fever • Rat model • Bronchoalveolar lavage $\bullet$ Lung homogenate

\section{Corresponding author}

A. Calkovska, Department of Physiology, Jessenius Faculty of Medicine, Comenius University, Mala Hora 4, SK-03601 Martin, Slovakia. E-mail: calkovska@jfmed.uniba.sk

\section{Introduction}

Bacterial lipopolysaccharide (LPS), or endotoxin, is a constituent of the bacterial cell membrane, which contributes to the local inflammation and systemic toxicity of Gram-negative infection (Canadas et al. 2011). Intratracheal administration of LPS elicits acute lung injury with an increase of inflammatory mediators in bronchoalveolar lavage (BAL) fluid and the recruitment of neutrophils into the air spaces (Uhlig et al. 1995, Mittal and Sanyal 2011, Shah et al. 2014). Moreover, inhaled LPS may interfere with surfactant membranes, resulting in surfactant dysfunction (Brogden et al. 1986, Canadas et al. 2011).

Systemic instillation of LPS elicits hypothermia and more often mono- , bi- or polyphasic rise in the body temperature (BT) and inflammatory response in laboratory animals depending on the serotype of LPS, the dose, the way of administration and ambient temperature (Rudaya et al. 2005, Wanner et al. 2013). Classical model of fever pathogenesis assumes an increase of the thermal setpoint by direct effects of pyrogens on hypothalamus (Dogan et al. 2000). An increase in body temperature modifies breathing pattern and contributes to respiratory instability in thermal stress (Voss et al. 2004).

Cardiorespiratory responses have been extensively studied in conditions of exogenous increase in core temperature by our group and others (e.g. Javorka et al. 1996, Brozmanova et al. 2006, Zila et al. 2007, Rubini 2011), but rarely in fever. In our recent study, rats with experimentally induced fever developed rapid shallow breathing with an increase in respiratory rate and decrease in tidal volumes typical for thermal tachypnea 
that was attributed to altered neural control of breathing (Zila et al. 2012).

Pulmonary surfactant is a complex of lipids and proteins that lines the inner surface of the alveoli and bronchioles to prevent lung collapse at the end of expiration. Beside several classes of lipids surfactant contains four specific proteins. Hydrophilic proteins SPA and SP-D belong to collectin family and are important for innate immunity within the lung (Haagsman et al. 2008). Hydrophobic proteins SP-B and SP-C play key roles in regulating surface tension as they promote adsorption and spreading of surfactant lipids at the airliquid interphase (Johansson 1998).

LPS-induced fever is mediated by cytokines (mainly interleukin $1 \beta$ a 6) and prostaglandin E2 that is central hypothalamic mediator during fever (Blatteis 2007). Interleukins are thought to be a link between infection, thermal stress and sleep apnoea in sudden infant death syndrome (SIDS) victims (Guntheroth 1989). Interleukins are responsible for thermoregulatory changes, influencing control of breathing and prolongation of apnoeic pauses (Fleming et al. 1993). Multi-factorial theory of SIDS assumes damage to pulmonary surfactant system as in children dying from SIDS changes in different surfactant components have been found (Hills et al. 1997, Stray-Pedersen et al. 2008). Up to now it is not known if penetration of exogenous pyrogen followed by fever contributes to surfactant inactivation, and if yes, whether it is due to changes in the body temperature, inflammation or changes in breathing pattern.

Based on literary data and our previous work, the aim of the study was to prove the hypothesis that changes in breathing pattern during LPS-induced fever might be, at least partially, related to changes in surfactant specific proteins playing a distinct role in the respiratory system.

\section{Methods}

Animals

The experiments were performed on 19 male adult rats (Wistar) with a body weight of $352 \pm 11 \mathrm{~g}$.

\section{Lipopolysaccharide (LPS)}

Purified lyophilized phenol extract of Escherichia coli (026:B6, Sigma) was dissolved in sterile saline and frozen in aliquots. Before use, the LPS was diluted in sterile saline and injected intraperitoneally.
The study design

The experiments were performed in accordance with European Guidelines on Laboratory Animal Care and the protocol was approved by the Local Ethics Committee of the Jessenius Faculty of Medicine, Comenius University in Martin, No. 968/2011.

The model is described elsewhere (Zila et al. 2012). Briefly, the animals were anaesthetized with intraperitoneal administration of $600 \mathrm{mg} \cdot \mathrm{kg}^{-1}$ urethane and $60 \mathrm{mg} \cdot \mathrm{kg}^{-1} \alpha$-chloralose. During the experiment, the anesthesia was maintained by $80 \mathrm{mg} / \mathrm{kg} / \mathrm{h}$ urethane and $4 \mathrm{mg} / \mathrm{kg} / \mathrm{h} \quad \alpha$-chloralose using continuous intravenous pump. The animals were tracheotomized and breathed spontaneously through a tracheal tube. The airflow was recorded through the Fleisch head of a pneumotachograph connected to the tracheal tube and tidal volume $\left(\mathrm{V}_{\mathrm{T}}\right)$ was obtained by electronic integration of the airflow signal (ADInstruments Pty Ltd.). The esophageal catheter was placed to record esophageal pressure during ventilation. Catheters were placed into a. femoralis for blood sampling and v.jugularis for intravenous infusion. Partial pressure of oxygen $\left(\mathrm{PO}_{2}\right)$ and carbon dioxide $\left(\mathrm{PCO}_{2}\right)$ and $\mathrm{pH}$ were analyzed in arterial blood by blood gas analyzer (Rapidlab; Bayer Diagnostics, Germany) and values were corrected for actual body temperature. Colonic body temperature was continuously measured with thermocouple (MiniLogger) inserted 4-5 cm into the anus.

The animals were randomly allocated into two groups. In LPS group $(\mathrm{n}=10)$, fever was induced by intraperitoneal administration of LPS (100 $\mu \mathrm{g} / \mathrm{kg}$ b.w.). Control group $(n=9)$ received an equivalent volume of sterile saline. Recordings of body temperature, ventilation parameters and blood gases were done before (T0) and every $60 \mathrm{~min}$ during $5 \mathrm{~h}$ after LPS or saline administration (T60-T300). At the end of experiments, animals were overdosed by Thiopental. The chest was open and the lungs were excised and processed as described below.

\section{Post mortem analyses}

The left lungs were lavaged by saline $(30 \mathrm{ml} / \mathrm{kg}$ b.w.). The recovered lavage fluid was centrifuged at $1500 \mathrm{~g}$ for $10 \mathrm{~min}$. Supernatant was removed and immediately frozen at $-20{ }^{\circ} \mathrm{C}$ prior analysis. Right lungs were processed as follows: The tissue was washed in cold PBS (0.02 mol/1, pH 7.0-7.2) and weighed. It was cut to small pieces and homogenized in PBS by homogenizer (POLYTRON ${ }^{\circledR}$ PT 1200, Kinematica AG, Switzerland) 
to final concentration $20 \%$. The suspension was subjected to two freeze-thaw cycles to further break the cell membranes. After that the homogenate was centrifuged at $1500 \mathrm{~g}$ for $15 \mathrm{~min}$ and supernatant was removed.

Total/differential white blood cell count was determined microscopically after staining by Pappenheim method in peripheral blood before and $5 \mathrm{~h}$ after LPS/saline instillation and in sediment of bronchoalveolar lavage fluid at the end of experiments.

Assays

The concentration of lipid peroxidation (LPO) products TBARS (thiobarbituric acid reactive substances) in plasma was determined by OxiSelect TBARS Assay Kit (STA-330; Cell Biolabs Inc.) and expressed in $\mu \mathrm{mol} / \mathrm{ml}$. The levels of surfactant specific proteins SP-A, SP-B, SP-C and SP-D were determined in lung tissue homogenate and bronchoalveolar lavage fluid (BALF), and aldosterone were determined in plasma by commercially available ELISA kits (BlueGene Biotech
Co. and Cusabio).

\section{Statistical analysis}

All data are shown as mean \pm SD. The statistical analysis was performed with STATISTICA Cz 10. Data were tested for normality of distribution using Kolmogorov-Smirnov test. Between- group differences were analyzed using Mann-Whitney test, and withingroup differences with Wilcoxon test. A P-value $<0.05$ was regarded as statistically significant.

\section{Results}

\section{Body temperature}

Instillation of lipopolysaccharide was accompanied by the rise in body temperature compared to saline-treated controls. Intraperitoneal administration of $100 \mu \mathrm{g} / \mathrm{kg}$ b.w. induced monophasic thermogenic response in all animals already in first registered time point (T60) with peak at $300 \mathrm{~min}$ after LPS (38.7 $\pm 0.2 \mathrm{vs.}$ $\left.36.4 \pm 0.3^{\circ} \mathrm{C}\right)(\mathrm{p}<0.05)$ (Fig. 1).

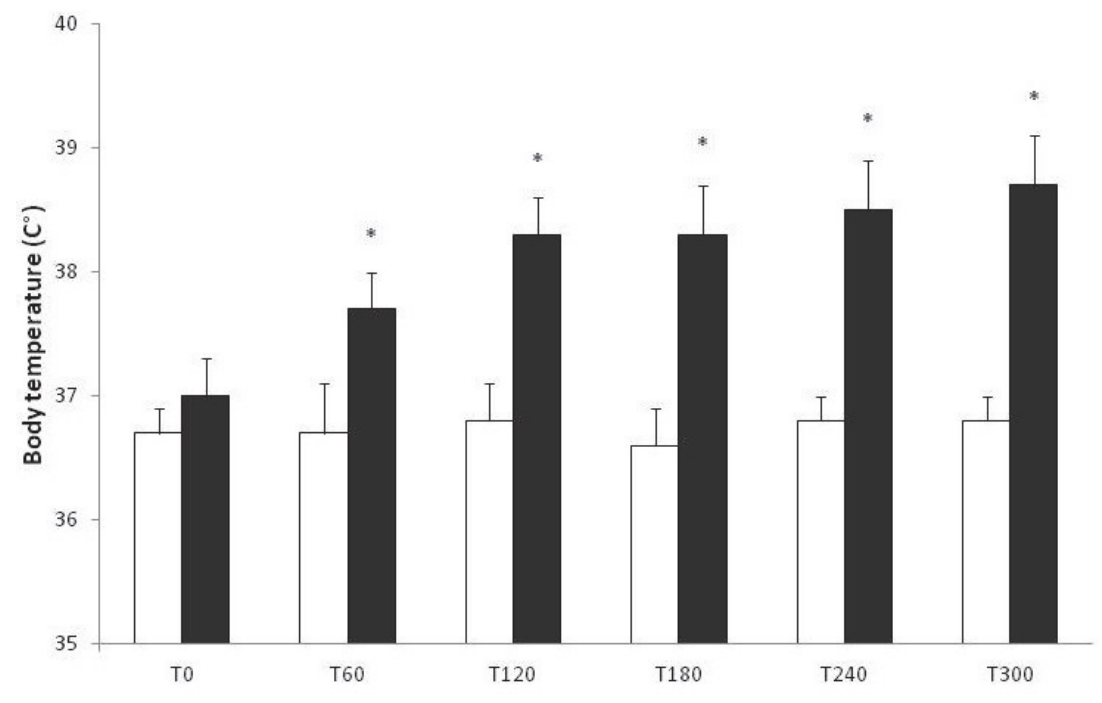

Fig. 1. Body temperature $\left({ }^{\circ} \mathrm{C}\right)$ measured before LPS/saline (T0) and $60,120,180,240$ and 300 min after LPS/saline instillation (T60-T300). Values are shown as mean and SD. LPS-group vs. control $* \mathrm{p}<0.05$. Empty bars - control, black bars LPS-instilled group

\section{TBARS and aldosterone}

Administration of endotoxin followed by febrile response evoked after $5 \mathrm{~h}$ a significant increase in TBARS in comparison with controls $(13.2 \pm 2 \mu \mathrm{mol} / \mathrm{ml}$ vs. $6.4 \pm 2.0 \mu \mathrm{mol} / \mathrm{ml} ; \mathrm{P}<0.01)$ and increase in aldosterone values $(423.5 \pm 115.7 \mathrm{pg} / \mathrm{ml}$ in controls vs. 1117.4 \pm 104.8 pg/ml in LPS-group; $\mathrm{P}<0.01$ ) (Fig. 2).

\section{Ventilation parameters}

The baseline values of tidal volume $\left(\mathrm{V}_{\mathrm{T}}\right)$, breathing rate (BR) and minute ventilation (MV) did not differ between the groups.

In controls, basic ventilation parameters before and at the end of experiment were unchanged. Before saline instillation (T0) $\mathrm{V}_{\mathrm{T}}$ was $2.0 \pm 0.3 \mathrm{ml}$, breathing rate (BR) was $98 \pm 12$ breaths per minute (bpm) and minute ventilation (MV) was $196 \pm 16 \mathrm{ml} / \mathrm{min}$. Five hours after instillation (T300) $\mathrm{V}_{\mathrm{T}}$ was $1.9 \pm 0.2 \mathrm{ml}$, BR $104 \pm 14 \mathrm{bpm}$ and MV $199 \pm 20 \mathrm{ml} / \mathrm{min}$ (all P vs. T0 >0.05). In LPS group, minute ventilation progressively increased with elevation of body temperature from $197 \pm 17 \mathrm{ml} / \mathrm{min}$ to $352 \pm 34 \mathrm{ml} / \mathrm{min}$ as a result of the rise of breathing rate 
from baseline $103 \pm 10 \mathrm{bpm}$ to $261 \pm 21 \mathrm{bpm}$ (both $P<0.01$ ) at $300 \mathrm{~min}$ after LPS administration. $\mathrm{V}_{\mathrm{T}}$ in LPS animals was reduced to $1.3 \pm 0.3 \mathrm{ml}$ (at T300) in comparison with baseline value $(1.9 \pm 0.3 \mathrm{ml}, P<0.05)$.
No significant differences were present in partial pressure of oxygen, carbon dioxide and $\mathrm{pH}$ between LPS and control groups or in values compared to baseline (Table 1).
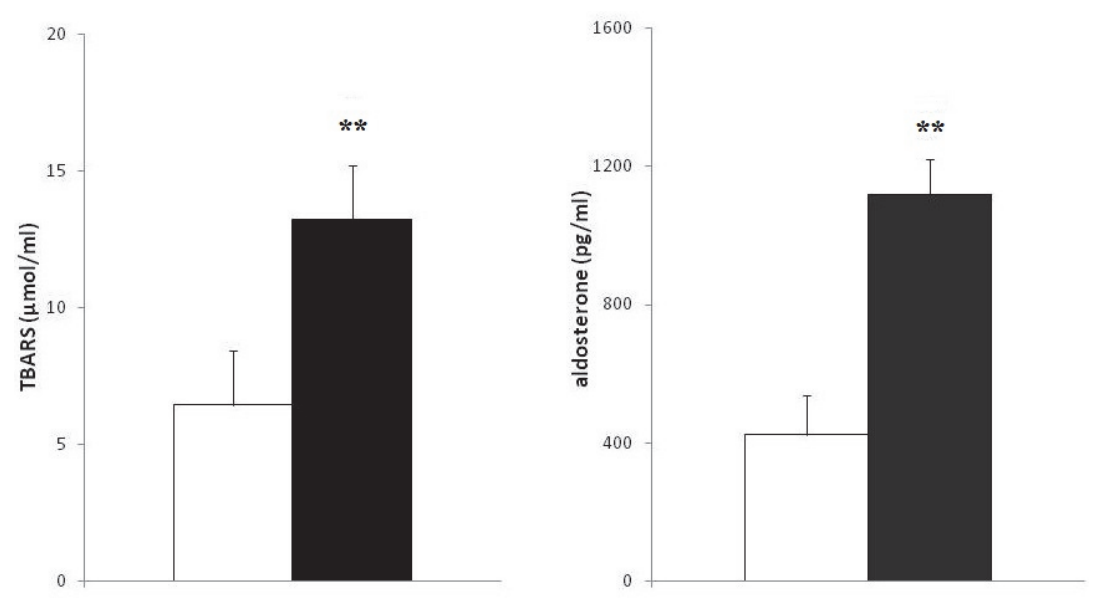

Fig. 2. The values of TBARS (thiobarbituric acid reactive substances) and aldosterone in plasma $300 \mathrm{~min}$ after LPS/saline administration. Values are shown as mean and SD. LPS-group vs. control $* * p<0.01$. Empty bars - control, black bars - LPS-instilled group

Table 1. The changes in $\mathrm{pH}$ and blood gases in the group with LPS-induced fever and control animals.

\begin{tabular}{lllllll}
\hline & \multicolumn{2}{c}{ LPS-group } & \multicolumn{4}{c}{ Saline-group } \\
\cline { 2 - 7 } & $\mathbf{P a O}_{\mathbf{2}}$ & $\mathbf{P a C O}_{\mathbf{2}}$ & $\mathbf{p H}$ & $\mathbf{P a O}_{\mathbf{2}}$ & $\mathbf{P a C O}_{\mathbf{2}}$ & $\mathbf{p H}$ \\
\hline Before LPS/S instillation & $10.8 \pm 0.4$ & $4.3 \pm 0.2$ & $7.36 \pm 0.02$ & $10.9 \pm 0.6$ & $4.1 \pm 0.3$ & $7.34 \pm 0.02$ \\
150 min after LPS/S & $10.0 \pm 0.4$ & $3.9 \pm 0.3$ & $7.38 \pm 0.01$ & $9.8 \pm 0.4$ & $3.6 \pm 0.1$ & $7.37 \pm 0.02$ \\
300 min after LPS/S & $9.7 \pm 0.5$ & $3.4 \pm 0.3$ & $7.38 \pm 0.01$ & $9.7 \pm 0.9$ & $3.3 \pm 0.5$ & $7.36 \pm 0.02$ \\
\hline
\end{tabular}

Data are shown as mean \pm SD. LPS - lipopolysaccharide, $\mathrm{S}-$ saline, $\mathrm{PaO}_{2}-$ arterial partial pressure of oxygen, $\mathrm{PaCO}_{2}-$ arterial partial pressure of carbon dioxide
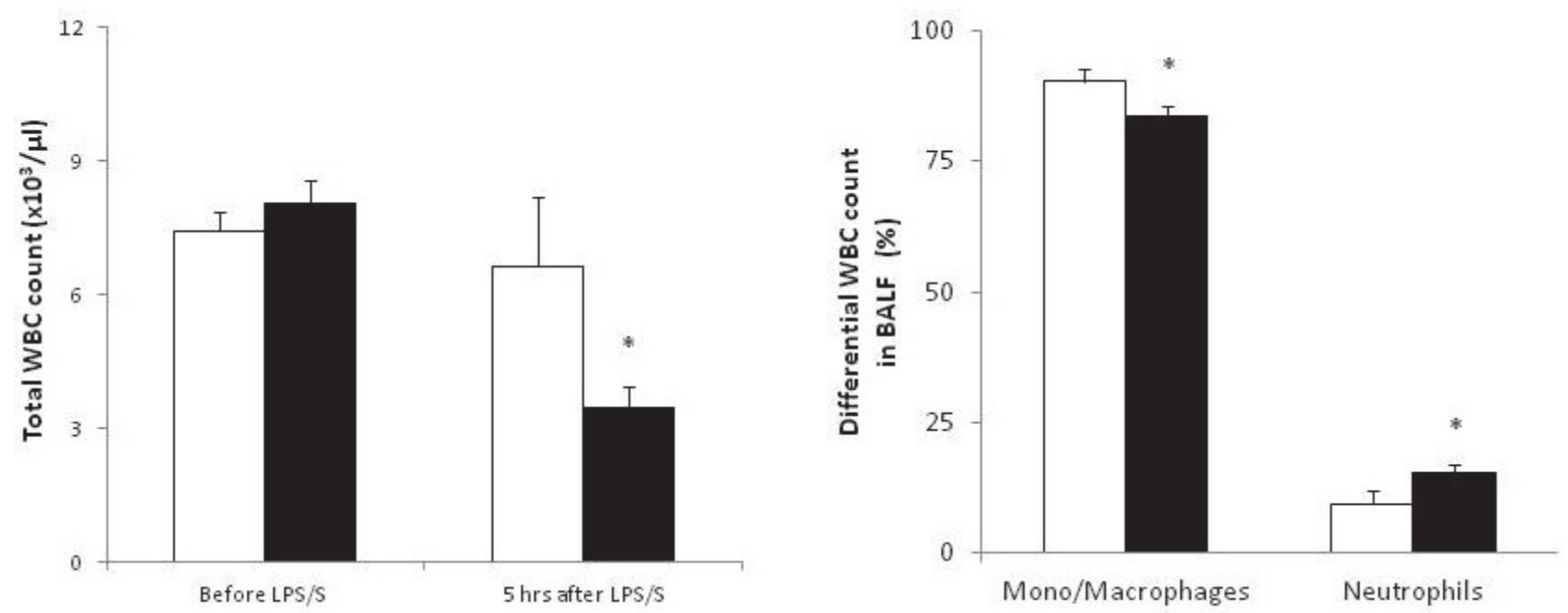

Fig. 3. Total white blood cell (WBC) count in peripheral blood before LPS/S and $5 \mathrm{~h}$ after LPS/S administration (left) and differential WBC count in bronchoalveolar lavage fluid (BALF) at the end experiment (right). Values are shown as mean and SD. LPS-group vs. control * $\mathrm{p}<0.05$. S - saline (empty bars), LPS - lipopolysaccharide (black bars), Mono - monocytes 


\section{White blood cell count}

There were no significant differences in the total white blood cell count between the groups before LPS or saline (S) instillation. Five hours after LPS/S administration animals with LPS-induced fever had significantly reduced total WBC count in comparison

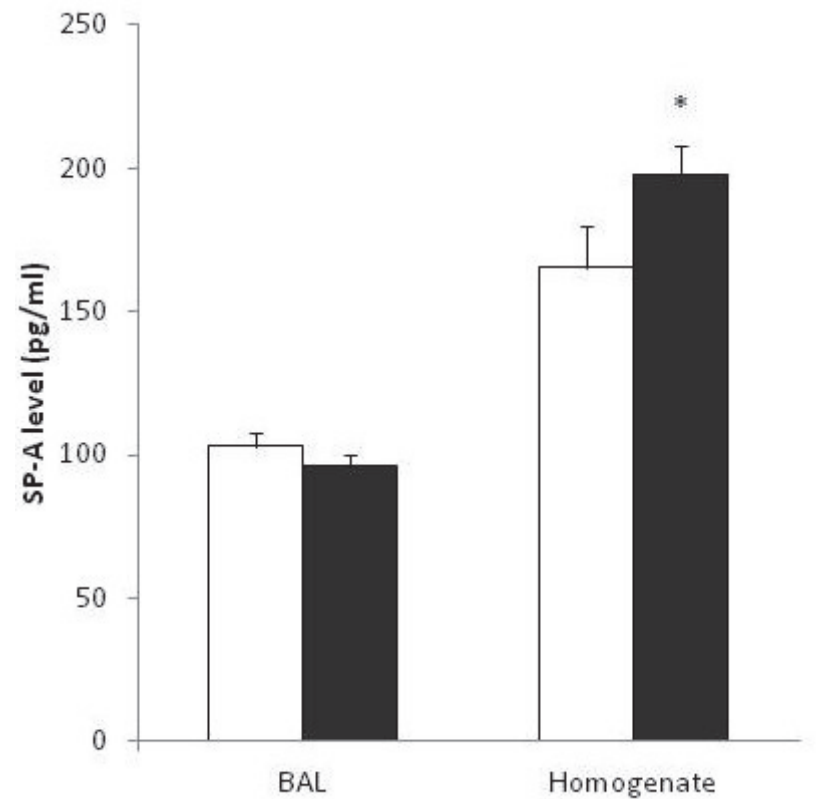

with saline-instilled animals $(\mathrm{P}<0.05)$ (Fig. 3). At the end of experiment animals with LPS-induced fever had significantly lower monocytes/macrophages count and increased neutrophils count in bronchoalveolar lavage fluid than animals receiving saline (both $\mathrm{P}<0.05$ ) (Fig. 3).

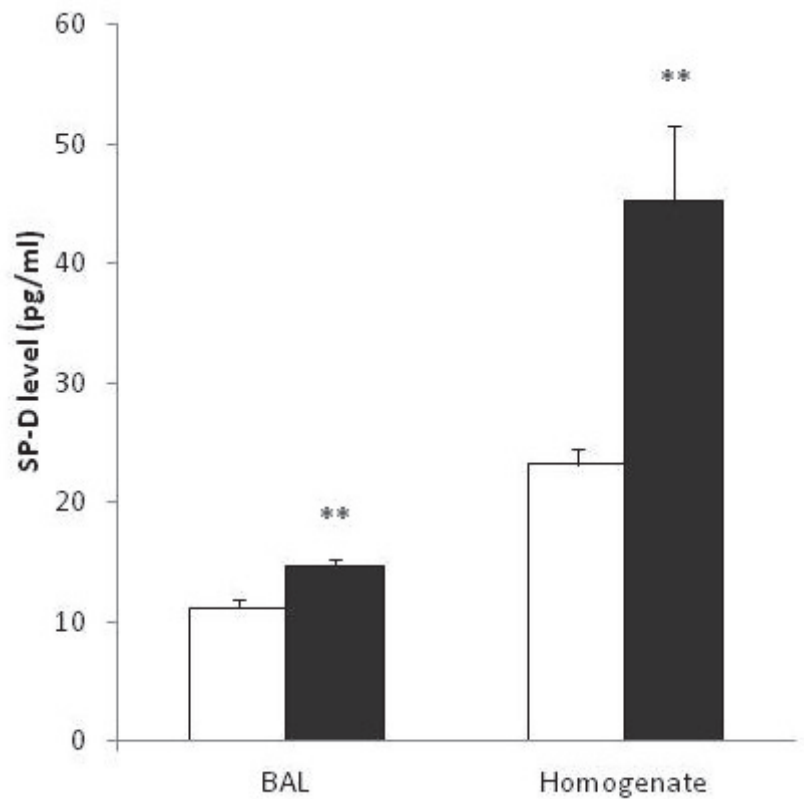

Fig. 4. The levels of surfactant proteins SP-A (left) and SP-D (right) in bronchoalveolar lavage (BAL) fluid and lung tissue homogenate in animals 300 min after saline (empty bars) and LPS (black bars) instillation. Values are shown as mean and SD. LPS-group vs. control $* * p<0.01, * p<0.05$
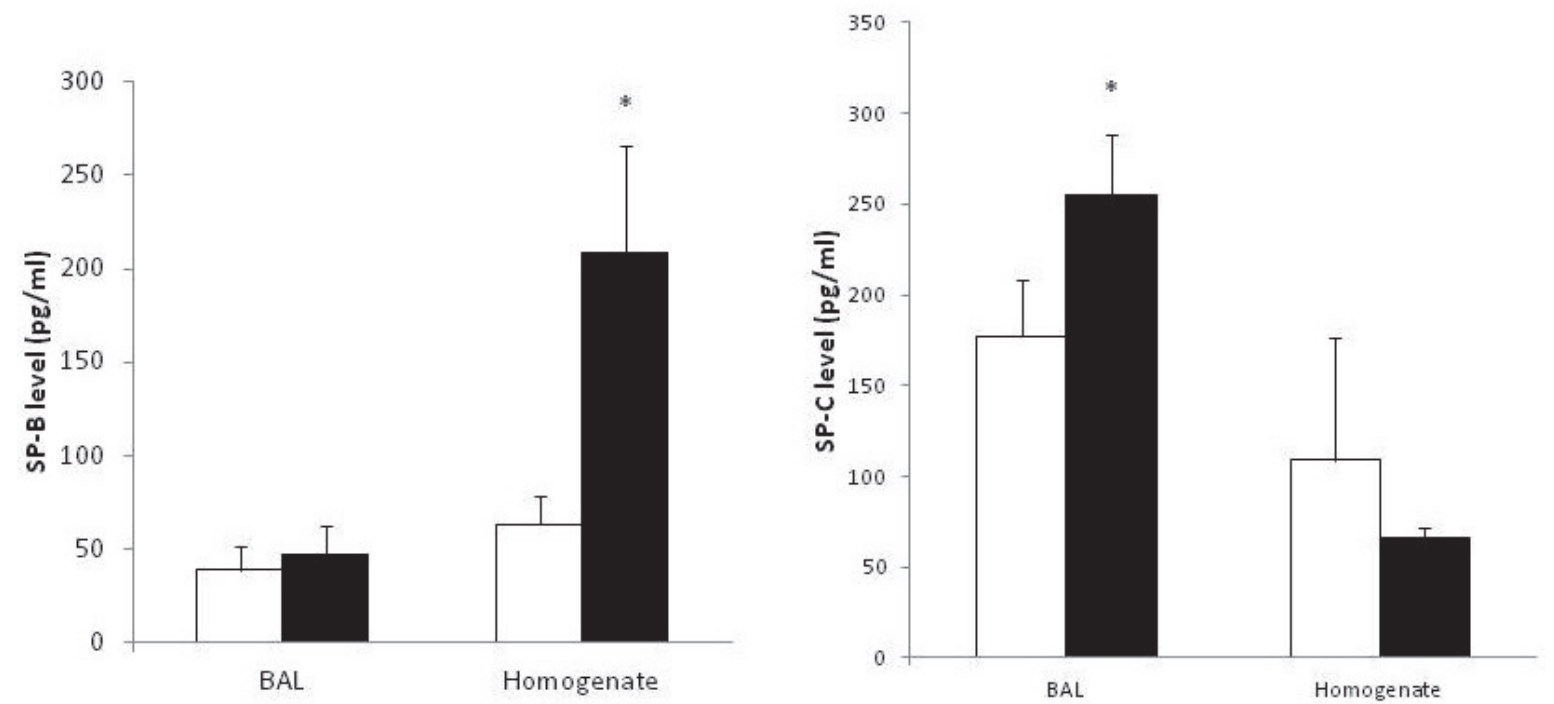

Fig. 5. The levels of surfactant proteins SP-B (left) and SP-C (right) in bronchoalveolar lavage (BAL) fluid and lung tissue homogenate in animals 300 min after saline (empty bars) and LPS (black bars) instillation. Values are shown as mean and SD. LPS-group vs. control $* * p<0.01, * p<0.05$ 
Surfactant specific proteins

\section{Surfactant proteins $A$ and $D$}

Both hydrophilic surfactant proteins SP-A and SP-D were present in increased amounts in lung tissue homogenate in LPS-instilled animals in comparison with controls; for SP-A $\mathrm{P}<0.05$ vs. control and for SP-D $\mathrm{P}<0.01$ vs. control (Fig. 4). In BAL fluid, levels of SP-A did not differ significantly between the groups, while SP$\mathrm{D}$ was present in significantly higher amount in LPS-group than in controls $(\mathrm{P}<0.01)$ (Fig. 4).

\section{Surfactant proteins $B$ and $C$}

The values of SP-B were increased significantly only in lung tissue in animals with LPS in comparison to controls $(\mathrm{P}<0.05)$ (Fig. 5). The differences in SP-C in lung tissue between LPS- and saline-instilled animals were not significant $(\mathrm{P}>0.05)$. SP-C was significantly higher in BAL fluid of animals with fever ( $<<0.05$ vs. control) (Fig. 5).

\section{Discussion}

In this study, in accordance with others (Werner et al. 2003, Sebai et al. 2009) intraperitoneal injection of LPS at the dose of $100 \mu \mathrm{g} / \mathrm{kg}$ of body weight (b.w.) evoked thermogenic response characterized by significant increase in core body temperature accompanied by increase of lipids peroxidation products TBARS and aldosterone in plasma, and changes in distribution of white blood cells in peripheral blood and bronchoalveolar lavage fluid.

At intravenous or intraperitoneal application the usual dose of LPS ranges from 10 to $100 \mu \mathrm{g} / \mathrm{kg}$ b.w. Based on literary data and our pilot experiments the dose of $100 \mu \mathrm{g} / \mathrm{kg}$ b.w. was chosen. This dose elicited higher maximal body temperature than the dose of $50 \mu \mathrm{g} / \mathrm{kg} \mathrm{b}$.w. and led to monophasic febrile response. The same model and the dose $100 \mu \mathrm{g} / \mathrm{kg}$ b.w. was also used in our previous study (Zila et al. 2012).

The onset of fever was followed by changes in breathing pattern known as thermal tachypnoea. During this pattern of ventilation, with an elevated functional residual capacity, a high frequency of breathing and a reduced tidal volume, the upper airways are preferentially ventilated and therefore blood gases and $\mathrm{pH}$ are maintained in a physiological range (White 2006). In our experiments, fever was accompanied by rapid shallow breathing with significant increase in respiratory rate and decrease in tidal volumes typical for thermal tachypnoea with no significant changes in blood gases and $\mathrm{pH}$ (Table 1). It is reasonable to suppose that the changes in pulmonary surfactant may occur with changes in body temperature and respiratory pattern. In experiments from early $90^{\text {th }}$ on excised lungs and anesthetized spontaneously breathing rats the effect of the ventilation rate and increase of the temperature was investigated by Massaro et al. (1981). They have detected changes in disaturated phosphatidylcholine in the lung lavage returns at higher rates of ventilation and higher temperature related to the loss of alveolar stability. In other study, alveolar stability was reduced despite the presence of normal amounts of airway surfactant (Massaro et al. 1983). It is also known that the monolayers of dipalmitoyl phosphatidylcholine (DPPC), the principal component of lung surfactant, become unstable at temperature $3-4{ }^{\circ} \mathrm{C}$ above their bulk lipid-water phase transition temperatures (Goerke and Gonzales 1981).

While it is relatively common to investigate the changes in pulmonary surfactant in hyperthermia, the effect of experimentally evoked fever on pulmonary surfactant is not known. We focused on all four surfactant specific proteins SP-A, -B, -C and -D. SP-A and SP-D are hydrophilic surfactant proteins involved mainly in local immune responses. In our study both SP-A and SP-D were present in higher amounts in lung tissue and SP-D also in BALF in LPS-instilled animals in comparison with controls. This is in contrast to studies when LPS was administered intratracheally in order to induce acute lung injury. In those studies, SP-A was reduced probably by binding to the lipid portion of LPS or enhanced clearance (Canadas et al. 2011).

For the other proteins, the values of SP-B were higher in lung tissue and SP-C in BALF in animals with LPS in comparison to controls. Surfactant specific proteins have different structure, metabolism and role in the respiratory system. Large hydrophilic proteins SP-A and SP-D belong to C-type lectins and have similar domain structure. In addition to primary role in pathogen clearance and inflammatory responses, SP-A is involved in formation of tubular myelin. SP-A and SP-D are secreted on alveolar surface in the lamellar body (LB)independent manner (Andreeva et al. 2007). Small hydrophobic polypeptides SP-B and SP-C are localized inside lamellar bodies and co-secreted with LB contents. SP-C is a transmembrane protein expressed exclusively by type II cells. It facilitates lipid movement between sheets of membrane and vesicles and functions along 
with SP-B to promote surfactant film formation. SP-C also stimulates reuptake of surfactant phospholipids by type II cells and is included in immune defense as mature SP-C contains LPS binding site (Mulugeta and Beers 2006).

The changes in surfactant specific proteins might occur as a result of the rise in body temperature, direct and indirect effect of LPS or changes in breathing pattern. As discussed above, the temperature is one of the variables that affect surface film formation at the airliquid interphase (Hobi et al. 2014). The core body temperature in rats receiving LPS in our study was approximately $38.7^{\circ} \mathrm{C}$, which is $2^{\circ} \mathrm{C}$ more than the normal body temperature. This is probably enough to cause phase transitions of surfactant lipids, because the upper limit of the phase transition in rats is $36.8^{\circ} \mathrm{C}$ (McMurchie et al. 1983). Higher amount of SP-C in BALF could reflect the need to stabilize the lungs.

Most of the changes observed in acute lung injury induced by inhalation of LPS are dependent on LPS signaling through the functional TLR4 (Toll-like receptor) on alveolar and immune cells (Garcia-Verdugo et al. 2008, Canadas et al. 2011). In the model of fever induced by intraperitoneal administration of LPS alveolar type (AT) II cells are not in direct contact with LPS and thus direct stimulation of AT II cells can be excluded. Stimulation of surfactant proteins release might be mediated through substances known to initiate signaling cascade for inflammatory mediator expression including cytokines such as tumor necrosis factor $\alpha$ (TNF- $\alpha$ ), interleukin (IL)-1 $\beta$ and 6 , inducible nitric oxide synthase and cyclooxygenase 2, and nuclear factor- $\kappa \mathrm{B}$ (Rossol et al. 2011, Soares et al. 2012). Moreover, many hormones secreted in response to fever may theoretically influence surfactant secretion. In recent study Cameron et al. (2010) found that even within the clinically relevant range of temperatures corticosteroid binding globulin acts as a protein thermocouple that is sensitive to temperature change and releases cortisol in response to fever. Cortisol is also known to promote fetal lung and surfactant system maturation (McGillick et al. 2013).

Both cytokines and LPS are able to induce the production of prostaglandin E2 (PGE2), an important mediator which alters the activity of neurons controlling body temperature, hypothalamus pituitary adrenal axis and behavioral responses (Hopkins 2007). Production of PGE2 is also accelerated by oxidative stress induced by LPS and mediated by reactive oxygen/nitrogen species (Nishio et al. 2013). Prostaglandin E2 is known to stimulate surfactant secretion from AT II cells (Morsy et al. 2001).

An increase in ventilation is a strong stimulus for surfactant secretion (Dobbs et al. 1991). Enhancement of minute ventilation by $100 \%$ by adding an extra dead space in rabbits leads to increase amount of surfactant phospholipids in BALF with maximum response $2 \mathrm{~h}$ after beginning of hyperventilation. After $2 \mathrm{~h}$ the amount of phospholipids in BALF falls probably due to reduction of intracellular pool or increase of its metabolism.

The surfactant secretion is stimulated by several mechanisms (Andreeva et al. 2007), some of them being mentioned above. Alveolar type II cells respond to $\beta$-agonists through receptors by increased surfactant secretion. Cholinergic stimulation is well documented in lower vertebrates and in hibernating mammals and is thought to play a role at low body temperatures, whereas type II cells of homoiothermic mammals (including humans) are not responsive to cholinergic agonists (Ormond et al. 2003). Cholinergic agonists still may affect surfactant secretion indirectly via activation of type II cell $\beta$-adrenergic receptors in response to catecholamines released from adrenal medulla. Mechanical stimuli (e.g. during inspiration) activate purinergic receptor $\mathrm{P}_{2} \mathrm{X}_{7}$ on AT I cells and releases ATP which binds on purinergic receptor P2Y2R on AT II cells (Mishra et al. 2011).

Not only the rate of synthesis and/or secretion but also the clearance of surfactant could play a role in alterations of surfactant proteins. SP-A promotes reuptake through one or more receptors. SP-B, SP-C and SP-D are also recycled, but there is no evidence for specific receptors for these proteins. In this point, important role is played by alveolar macrophages that are involved in degradation and recycling of surfactant components within alveolus (Andreeva et al. 2007). Even if the relative number of macrophages in BAL fluid in our experiments was reduced in LPS-instilled animals with fever, this possibility cannot be ruled out with certainty as the metabolic activity of macrophages was not measured.

It seems that mechanisms leading to changes in surfactant proteins secretion in LPS-induced fever are complex. Humoral and neural pathways activated by LPS administration lead to increase in body temperature accompanied by changes in breathing pattern and followed by augmented surfactant proteins secretion probably as an adaptive response of the alveolar epithelium to LPS challenge and alveolar instability. 


\section{Conclusion}

LPS-induced fever leads to changes in all surfactant specific proteins. Changes in proteins related to local immune mechanisms (SP-A, SP-D) are probably evoked by general inflammatory response of the body after exogenous pyrogen administration. Changes in proteins related to surface activity (SP-B and SP-C) might reflect the effort of the body to stabilize the lungs during alterations of breathing pattern in thermal challenge.

\section{Conflict of Interest}

There is no conflict of interest.

\section{Acknowledgements}

Authors thank D. Kuliskova, Ing. M. Petraskova and Ing. M. Hutko for technical assistance. The study was supported by projects APVV-0435-11, VEGA 1/416/12, UK/171/2014 and BioMed, co-financed from EU sources.

\section{References}

ANDREEVA VA, KUTUZOV MA, VOYNO-YASENETSKAYA TA: Regulation of surfactant secretion in alveolar type II cells. Am J Physiol 293: L259-L271, 2007.

BLATTEIS CM: The onset of fever: new insights into its mechanism. Prog Brain Res 162: 3-14, 2007.

BROGDEN KA, CUTLIP RC, LEHMKUHL HD: Complexing of bacterial lipopolysaccharide with lung surfactant. Infect Immun 52: 644-649, 1986.

BROZMANOVA A, JOCHEM J, JAVORKA K, ZILA I, ZWIRSKA-KORCZALA K: Effects of diuretic-induced hypovolemia/isosmotic dehydration on cardiorespiratory responses to hyperthermia and its physical treatment. Int J Hyperthermia 22: 135-147, 2006.

CAMERON A, HENLEY D, CARRELL R, ZHOU A, CLARKE A, LIGHTMAN S: Temperature-responsive release of cortisol from its binding globulin: a protein thermocouple. J Clin Endocrinol Metab 95: 4689-4695, 2010.

DOBBS LG, WIRTZ HRW, PIAN MS: Regulation of surfactant secretion in cultured type II cells. In: Basic Research on Lung Surfactant. VON WICHERT P, MÜLLER B (eds), Karger, Basel, 1990, pp 115-121.

DOGAN DM, ATAOGLU H, AKARSU ES: Effects of different serotypes of Escherichia coli lipopolysaccharides on body temperature in rats. Life Sci 67: 2319-2329, 2000.

FLEMING PJ, LEVINE MR, ASAZ Y, WIGFIELD R, STEWART AJ: Interactions between thermoregulation and the control of respiration in infants: possible relationship to sudden infant death. Acta Paediatr 82 (Suppl 389): 57 59, 1993.

GARCIA-VERDUGO I, RAVASIO A, GARCIA DE PACO E, SYNGUELAKIS M, IVANOVA N, KANELLOPOULOS J, HALLER T: Long-term exposure to LPS enhances the rate of stimulated exocytosis and surfactant secretion in type II cells and upregulates P2Y2 receptor expression. Am J Physiol 295: L708L717, 2008.

GOERKE J, GONZALES J: Temperature dependence of dipalmitoyl phosphatidylcholine monolayer stability. $J$ Appl Physiol Respir Environ Exerc Physiol 51: 1108-1114, 1981.

GUNTHEROTH WG: Interleukin 1 as intermediary causing a prolonged sleep apnea and SIDS during respiratory infections. Med Hypotheses 28: 121-123, 1989.

HAAGSMAN HP, HOGENKAMP A, VAN EIJK M, VELDHUIZEN EJ: Surfactant collectins and innate immunity. Neonatology 93: 288-294, 2008.

HILLS BA, MASTERS IB, VANCE JC, HILLS YC: Abnormalities in surfactant in sudden infant death syndrome as a postmortem marker and possible test of risk. J Pediatr Child Health 33: 61-66, 1997.

HOBI N, SIBER G, BOUZAS V, RAVASIO A, PÉREZ-GIL J, HALLER T: Physiological variables affecting surface film formation by native lamellar body-like pulmonary surfactant particles. Biochim Biophys Acta 1838: 18421850, 2014.

HOPKINS SJ: Central nervous system recognition of peripheral inflammation: a neural, hormonal collaboration. Acta Biomed 78 (Suppl 1): 231-247, 2007.

JAVORKA K, CALKOVSKA A, PETRASKOVA M, GECELOVSKA V: Cardiorespiratory parameters and respiratory reflexes in rabbits during hyperthermia. Physiol Res 45: 439-447, 1996. 
JOHANSSON J: Structure and properties of surfactant protein C. Biochim Biophys Acta 1408: 161-172, 1998.

MASSARO D, CLERCH L, MASSARO GD: Surfactant aggregation in rat lungs: influence of temperature and ventilation. J Appl Physiol Respir Environ Exerc Physiol 51: 646-653, 1981.

MASSARO D, CLERCH L, TEMPLE D, BAIER H: Surfactant deficiency in rats without a decreased amount of extracellular surfactant. J Clin Invest 71: 1536-1543, 1983.

MCGILLICK EV, ORGEIG S, MCMILLEN IC, MORRISON JL: The fetal sheep lung does not respond to cortisol infusion during the late canalicular phase of development. Physiol Rep 1: e00130, 2013.

MCMURCHIE EJ, TEUBNER JK, GIBSON RA: Thermal phase transitions in sheep, rat and rabbit surfactant lipids detected by differential scanning calorimetry. Comp Biochem Physiol A Comp Physiol 74: 295-299, 1983.

MISHRA A, CHINTAGARI NR, GUO Y, WENG T, SU L, LIU L: Purinergic P2X7 receptor regulates lung surfactant secretion in a paracrine manner. J Cell Sci 124: 657-668, 2011.

MITTAL N, SANYAL SN: In vivo effect of surfactant on inflammatory cytokines during endotoxin-induced lung injury in rodents. $J$ Immunotoxicol 8: 274-283, 2011.

MORSY M, ISOHAMA Y, MIYATA T: Prostaglandin E2 increases surfactant secretion via the EP1 receptor in rat alveolar type II cells. Eur J Pharmacol 426: 21-24, 2001.

MULUGETA S, BEERS MF: Surfactant protein C: Its unique properties and emerging immunomodulatory role in the lung. Microbes Infect 8: 2317-2323, 2006.

NISHIO K, HORIE M, AKAZAWA Y, SHICHIRI M, IWAHASHI H, HAGIHARA Y, YOSHIDA Y, NIKI E: Attenuation of lipopolysaccharide (LPS)-induced cytotoxicity by tocopherols and tocotrienols. Redox Biol 1: 97-103, 2013.

ORMOND CJ, ORGEIG S, DANIELS CB, MILSOM WK: Thermal acclimation of surfactant secretion and its regulation by adrenergic and cholinergic agonists in type II cells isolated from warm-active and torpid goldenmantled ground squirrels, Spermophilus lateralis. J Exp Biol 206: 3031-3041, 2003.

ROSSOL M, HEIN H, MEUSCH U, QUANDT D, KLEIN C, SWEET MJ, HAUSCHILDT S: LPS-induced cytokine production in human monocytes and macrophages. Crit Rev Immunol 31: 379-446, 2011.

RUBINI A: The effect of body warming on respiratory mechanics in rats. Respir Physiol Neurobiol 175: 255-260, 2011.

RUDAYA AY, STEINER AA, ROBBINS JR, DRAGIC AS, ROMANOVSKY AA: Thermoregulatory responses to lipopolysaccharide in the mouse: dependence on the dose and ambient temperature. Am J Physiol 289: R1244R1252, 2005.

SEBAI H, BEN-ATTIA M, SANI M, AOUANI E, GHANEM-BOUGHANMI N: Protective effect of resveratrol in endotoxemia-induced acute phase response in rats. Arch Toxicol 83: 335-340, 2009.

SHAH D, ROMERO F, STAFSTROM W, DUONG M, SUMMER R: Extracellular ATP mediates the late phase of neutrophil recruitment to the lung in murine models of acute lung injury. Am J Physiol 306: L152-L161, 2014.

SOARES DM, FIGUEIREDO MJ, MARTINS JM, MACHADO RR, SORGI C, FACIOLLI LH, ALVES-FILHO JC, CUNHA FQ, SOUZA GE: A crucial role for IL-6 in the CNS of rats during fever induced by the injection of live E. coli. Med Microbiol Immunol 201: 47-60, 2012.

STRAY-PEDERSEN A, VEGE A, STRAY-PEDERSEN A, HOLMSKOV U, ROGNUM TO: Post-neonatal drop in alveolar SP-A expression: biological significance for increased vulnerability to SIDS? Pediatr Pulmonol 43: 160-168, 2008.

UHLIG S, BRASCH F, WOLLIN L, FEHRENBACH H, RICHTER J, WENDEL A: Functional and fine structural changes in isolated rat lungs challenged with endotoxin ex vivo and in vitro. Am J Pathol 146: 1235-1247, 1995.

VOSS LJ, BOLTON DPG, GALLAND BC, TAYLOR BJ: Endotoxin effects on markers of autonomic nervous system function in the piglet: implications for SIDS. Biol Neonate 86: 39-47, 2004.

WANNER SP, YOSHIDA K, KULCHITSKY VA, IVANOV AI, KANOSUE K, ROMANOVSKY AA: Lipopolysaccharide-induced neuronal activation in the paraventricular and dorsomedial hypothalamus depends on ambient temperature. PLoS One 8: e75733, 2013.

WERNER MF, FRAGA D, MELO MC, SOUZA GE, ZAMPRONIO AR: Importance of the vagus nerve for fever and neutrophil migration induced by intraperitoneal LPS injection. Inflamm Res 52: 291-296, 2003. 
WHITE MD: Components and mechanisms of thermal hyperpnea. J Appl Physiol 101: 655-663, 2006.

ZILA I, BROZMANOVA A, JAVORKA M, CALKOVSKA A, JAVORKA K: Effects of hypovolemia on hypercapnic ventilatory response in experimental hyperthermia. J Physiol Pharmacol 58 (Suppl 5): 781-790, 2007.

ZILA I, MOKRA D, JAVORKA M, JAVORKA K, CALKOVSKA A: Lipopolysaccharide-induced fever alters HeringBreuer reflex in anesthetized rats. J Therm Biol 37: 475-478, 2012. 